\title{
Peningkatan Kemampuan Hafalan Bacaan Sholat Anak Usia 6 Tahun Melalui Metode Pembiasaan
}

\author{
Desy Ayuningrum \\ Fakultas Tarbiyah Institut PTIQ Jakarta, Indonesia \\ desyayuningrum14@gmail.com
}

\begin{abstract}
Abstrak:
Penelitian dilaksanakan di Jalan Pondok Cabe 1 no 97, Pamulang Banten. Alokasi waktu dilapangan dilakukan pada bulan November sampai dengan Desember 2016. Subjek penelitian adalah anak TK B usia 6 tahun sebanyak 1 anak. Penelitian tindakan menggunakan desain Kemmis dan Mc. Taggart. Desain ini berisikan tahapan mulai dari perencanaan, tindakan, observasi dan refleksi. Pengumpulan data menggunakan lembar asesmen, observasi, catatan lapangan dan dokumentasi. Analisa data menggunakan observasi maupun tes perbuatan dengan analisa deskriptif kualitatif berdasarkan hasil observasi dan refleksi. Penelitian dibagi menjadi tiga siklus, satu siklus terdiri atas dua minggu, siklus pertama di minggu pertama ketuntasan $\mathrm{S}$ pada angka 36\% kemudian terus meningkat di siklus kedua yaitu $72 \%$ dan siklus ketiga mencapai 90\%, dari 11 target hafalan 10 hafalan telah dicapai.
\end{abstract}

Kata Kunci: Kemampuan Menghafal, Metode Pembiasaan, Anak

\begin{abstract}
:
The study was conducted at Jalan Pondok Cabe 1 no 97, Pamulang Banten. The time allocation in the field was carried out from November to December 2016. The subject of the study was 1 child of B Kindergarten aged 6 years. Action research using Kemmis and Mc. Taggart. This design contains stages starting from planning, action, observation and reflection. Data collection uses assessment sheets, observations, field notes and documentation. Analysis of data using observations and tests of action with qualitative descriptive analysis based on the results of
\end{abstract}


Peningkatan Kemampuan Hafalan Bacaan Sholat

Anak Usia 6 Tahun Melalui Metode Pembiasaan

observation and reflection. The study was divided into three cycles, one cycle consisting of two weeks, the first cycle in the first week completing $\mathrm{S}$ at $36 \%$ then continued to increase in the second cycle of $72 \%$ and the third cycle reached $90 \%$, from 11 memorization targets 10 memorization had been achieved.

Keywords: Ability to Memorize, Habitual Methods, Children

\section{Pendahuluan}

Shalat merupakan bentuk ibadah kepada Allah SWT yang paling tinggi nilainya. Shalat adalah ibadah yang terdiri dari gerakan anggota badan (fi'liyah) dan ucapan atau bacaan ( qauliyah ). Fi'liyah dan qauliyah adalah integral artinya sebagai satu ksatuan utuh yang tidak dapat dipisahkan. Shalat akan sah apabila fi'liyah dan qauliyah dikerjakan dengan benar. Karena fi'liyah dan qauliyah adalah integral maka bacaan shalat harus hafal, artinya tidak membaca tulisan. Disamping itu penghayatan makna bacaan shalat akan mudah meresap dalam hati jika bacaan itu sudah dihafal dengan lancar.

Perkembangan pemerolehan bahasa dalam hal kemampuan untuk mengucapkan huruf adalah bersifat kodrati dan universal maka di pastikan bahwa pada setiap otak manusia tersedia tempat untuk ruang bahasa yang siap menerima masukan melalui interaksi komunikasi antara anak dengan orang lain di lingkungannya (Chomsky, 2000) Sebenarnya bahasa lingkungan yang paling dominan adalah bahasa ibu kandung anak. Dengan kata lain, bahasa ibu akan diwariskan pada bahasa anak atau ibu sangat berperan dalam pemerolehan kata dalam perkembangan bahasa anak. $^{1}$

Seorang ibu yang bijaksana tentu tidak akan menyia-nyiakan kesempatan emas ini untuk mendidik atau mengarahkan anak-anaknya dengan memasukkan kata-kata yang baik dan bermanfaat untuk kehidupan anak. Ibu yang bijak akan memanfaatkan waktu bersama dengan anaknya semaksimal mungkin untuk memperkenalkan kata-kata yang baik dan bermanfaat, salah satunya adalah mengajarkan bacaan sholat pada anak.

${ }^{1}$ Zakiah Darajat, Pendidikan Islam dalam Keluarga dan Sekolah, (Jakarta: CV Ruhama, 1995) dalam skripsi Parsaulian, Sari Domu, Studi Perkembangan Kemampuan Menghapal Surat Al-Fatihah Anak Usia 5 Tahun Di Kampung Teleng Padang Sidempuan, 2007 
Desy Ayuningrum

Usia anak umur 5 tahun adalah waktu yang paling ideal untuk menghafal. Pada usia tersebut informasi yang diterima anak akan sangat membekas pada jiwa anak. Apa saja yang diperoleh akan dikenang sepanjang hayatnya.

Salah satu upaya yang dapat dilakukan untuk mempermudah menghafal adalah metode pembiasaan. Pembiasaan adalah salah satu alat pendidikan yang penting sekali terutama bagi anak-anak. Metode pembiasaan yaitu cara pembelajaran dengan memberikan stressing atau tekanan terhadap suatu pelajaran. ${ }^{2}$ Dengan pembiasaan secara terus menerus dalam jangka waktu yang terukur anak didik atau siswa terbukti dapat mengingat materi yang dihafalkan.

Permasalahan dalam dunia pendidikan saat ini adalah kemerosotan moral dan akhlak bangsa Indonesia , khususnya generasi muda sangat dirasakan. Indikasi hal itu begitu nyata di depan mata seperti beredarnya gambar-gambar porno, peredaran obat-obat terlarang, tindakan asusila dikalangan pelajar dan masih banyak lagi contoh tentang kemerosotan moral. Semua ini adalah sebagian dari akibat dari globalisasi yang kini melanda. Disamping itu juga adanya erosi nilai sebagai akibat dari melemahnya iman dan akhlaq. Orang yang imannya kuat pasti akhlaqnya akan baik.

Sholat adalah sarana untuk memperkuat iman. Shalat yang diamalkan dengan penuh penghayatan pasti dapat membentuk kepribadian yang baik. Penghayatan makna shalat hanya dapat dicapai dengan pembiasaan pengamalan shalat sejak dini. Pembiasaan shalat sejak usia sekolah mesti dimulai dengan hafalan bacaan shalat secara utuh, artinya tidak terpisah antara bacaan yang merupakan rukun shalat dan bacaan yang sunat.

\section{Perkembangan Pemerolehan Bahasa Anak}

Sejak minggu-minggu pertama sesudah lahir anak mulai menunjukkan niat komunikasi yang antara lain dengan tersenyum, menarik sesuatu, menoleh pada arah cahaya dan suara, menangis bila pakaiannya basah dan mampu membedakan digendong ibunya dengan digendong orang lain. Setelah perkembangan kinestetik dan biologisnya memadai untuk melakukan komunikasi, maka komunikasi itu di wujudkan dalam bentuk bunyi.

2Abu Ahmadi., Drs., H., Munawar Sholeh, Psikologi Perkembangan. Cetakan I. Jakarta : Rineka Cipta. 2005, h. 118. 
Peningkatan Kemampuan Hafalan Bacaan Sholat

Anak Usia 6 Tahun Melalui Metode Pembiasaan

Bunyi yang dikeluarkan anak dalam berkomunikasi adalah bunyi atau kata yang diperoleh anak dari bahasa atau kata yang sudah disuguhkan kepadanya yang di pahaminya maupun tidak dipahaminya.

Pemerolehan kata pada anak berlaku sama atau universal yang berarti kemampuan anak dalam menyimpan dan mengeluarkan huruf adalah berlaku sama pada setiap anak seperti: ${ }^{3}$

1. Pada umur 0-8 minggu anak hanya mengeluarkan bunyi refleksif berupa tangisan, batuk, bersin dan sebagainya.

2. Pada umur 2-5 bulan anak mulai mendekut dan mengeluarkan bunyi seperti vocal dan seperti konsonan.

3. Pada umur 4-7 bulan anak mulai mengeluarkan bunyi yang agak utuh.

4. Pada umur 6-12 bulan anak sudah mengeluarkan celotehan kata ulang satu suku kata.

5. Dan untuk anak normal usia 18 bulan anak mampu mengeluarkan kata yang utuh dalam dua suku kata untuk satu kata sekaligus menguasai penggunaan lebih dari tiga kata akan tetapi kurang dari 50 kata dan pada usia ini seorang anak yang normal akan mulai mengeluarkan bunyi kata-kata yang di peroleh dari lingkungannya sejak hari pertama dia dilahirkan, walaupun kosa kata yang mampu difahami berbeda lebih banyak dari jumlah kosa kata yang mampu diucapkan (dikeluarkan) perbandingan kemampuan anak untuk memahami atau komprehensi adalah lima kali lebih banyak dari kemampuan anak untuk mengucapkannya, sehingga pada usia 1 tahun 8 bulan seorang anak hanya mampu mengucapkan 10 kata yang berisikan dua suku kata. Dilihat dari keterbatasan kemampuan anak pada usia awal mampu untuk menyerap, memahami serta mengeluarkan kata dibandingkan dengan masukan masukan yang dia dengar atau dia lihat maka pada seorang anak masa ini sering menyamakan suatu konsep benda dengan nama benda yang lain.

6. Bila nama yang pertama kali didengar dan dilihat oleh seorang anak untuk suatu nama hewan "kambing” maka kata kambing akan dia gunakan juga untuk seekor domba, anjing, rusa dll yang ukuran besar hewannya hampir sama dengan kambing.

7. Nama sebuah buku akan sama untuk sebuah majalah, kamus, alqur'an, namun bila nama Alquran yang di tunjukkan dan diperdengarkan pertama kali maka nama alqur'an akan mewakili nama benda yang sama.

${ }^{3}$ Eve V Clark, Old and New Words Forms for New Meaning dalam Men and Ratna, coining new words: 2000.

IQ (Ilmu Al-qur'an): Jurnal Pendidikan Islam | Volume 1 No.02 $2018 \mid 175$ 
8. Nama pensil untuk pulpen, kelir untuk spidol atau alat tulis lainnya.

Pada usia ini seorang anak juga sering mengunakan satu kata saja untuk satu kalimat, secara sintaksis suara yang keluar cukup sederhana namun dari semantisnya ujaran satu kata itu cukup lengkap atau multi arah, satu kata hanya dapat ditafsirkan sesuai dengan situasi saat berbicara dan kata itu belum tentu bermakna tunggal seperti :

saat seorang anak mengatakan [oyat] bisa bermakna (a) saya mau sholat, (b) dia menunjukkan pada seorang sedang sholat, (c) dia menyuruh kawan berbicaranya sholat, (d) atau saat dia mendengar adzan dia mengajak kawan bicaranya untuk sholat bersama. Saat seorang anak menyebut nama seseorang ( mam ) bila bermakna (a) Tulang Imam, (b) Abang Imam (c) kawannya bernama Imam atau (d) Adek Imam.

Bila beberapa urutan kata diperdengarkan pada seorang anak pada saat ini maka anak akan menyebutkan urutan yang pertama saja atau urutan yang terakhir saja mewakili semua kata yang diperdengarkan. Penafsiran semamtis ujarannya menjadi agak lebih dimengerti setelah pemerolehan bahasa anak masuk pada tahap yang lebih semprna yaitu pada tahap dua suku kata pada usia dua tahun, Evc clark mengungkapkan bahwa sejak umur dua tahun anak akan menambah kemampuan ujarannya sekitar 10 kata baru perhari sehingga pada umur enam tahun seorang anak sudah akan mampu memperoleh 14.000 kata.

Bila pemerolehan bahasa ini bersifat kodrati dan merupakan suatu proses lanjut dan berjalan secara konstan dari waktu ke waktu dengan mengikuti tahapan-tahapan perkembangan bahasa universal. Seorang anak tidak bisa dipaksakan untuk mempercepat suatu tahapan kemampuan dan tidak bisa diperlambat sehingga seorang anak tidak bisa dipaksakan untuk mampu mengucapkan suatu huruf bila belum sampai pada tahap perkembangan bahasanya dan seorang anak tidak bisa dihalangi untuk mampu mengucapkan suatu huruf bila sudah sampai pada masa perkembangan bahasanya.

\section{Hafalan Bacaan Sholat}

\section{Pengertian Hafalan}

Menurut Kamus Besar Bahasa Indonesia (KBBI) hafalan berupa kata yang dasarnya adalah hafal, maksudnya (1) Telah masuk dalam ingatan (tentang pelajaran). Saya sudah mempelajari dan juga hafal isinya; (2) Dapat mengucapkan di luar kepala (tanpa melihat buku atau catatan lain).

176 | IQ (Ilmu Al-qur'an): Jurnal Pendidikan Islam | Volume 1 No.02 2018 


\section{Pengertian Bacaan Sholat}

Menurut Al-Quran dan Hadits bacaan yang diucapkan ketika ibadah sholat, yaitu:

a. Niat

Contoh niat sholat subuh:

“Ushollii Fardlolsh Shubhi Rok'ataini Mustaqbilal Qiblati Adaa-An (Imaaman/Ma'muuman) Lillaahi Ta'aalaa".

b. Takbiratul Ikhram

"Allaahu Akbar".

c. Bacaan Do'a Iftitah

“Allahu Akbar, Kabiiraw Walhamdulillahi Katsira Wasubhanallahi Bukrataw Wa-Ashila.

Wajjahtu Wajhia Lilladzi Fatharas Samawati Wal Ardla Hanifan Muslimawwama Anaminal Musyrikin. Inna Shalati Wanusuki Wamahyaya Wamamati Lillahi Rabbil'alamin. Lasyarakika Lahu Wabidzalika Umirtu Wa Ana Minal Muslimiin”.

d. Bacaan Al-Fatihah

"Bismilla-Hirrahma Nirrahim. Alhamdu Lillahi-Robbil 'Alamin. Arrahma Nirrahim. Maliki Yaumiddin. Iyyaka Na'budu Waiyya-Kanasta'in Ihdinash-Shira-Thal Mustaqim, Shirathalladzina An'amta'alaihim Ghairil Maghdhubi 'Alaihim. Waladl Dlaalliin, Amin'.

e. Bacaan Surat Quran Pendek

f. Ruku'

"Subhaana Rabbiyal Adziimi Wabihamdihii" ( 3 kali) .

g. I'tidal

"Sami'allaahu Liman Hamidah Rabbana Wa Lakal Hamdu”.

h. Sujud

"Subhaana Rabbiyal A'laa Wabihamdihii" (3 kali).

i. Duduk diantara dua sujud

“Rabbighfirlii Warhamnii Wajburnii Warfa'nii Warzuqnii Wahdinii Wa'aafini Wa'fuannii”.

j. Tahiyat awal

“Attahiyyatul Mubarakaatush Sholawaatuth Thayyibatu Lillaah, Assalaamu'alaika Ayyuhan

Nabiyyu Warahmatullaahi Wabarakaatuh, Assalaamu'alaina Wa'alaa 'Ibaadillaahish 
Desy Ayuningrum

Shoolihiin. Asyhadu Allaa Ilaaha Illallaah, Waasyhadu Anna Muhammadan Rasuulullaah. Allahhumma Sholli 'Alaa Saidina Muhammad Wa 'Ala Aalihi Saidina Muhammad'.

k. Tahiyat akhir

“Attahiyyatul Mubarakaatush Sholawaatuth Thayyibatu Lillaah, Assalaamu'alaika Ayyuhan Nabiyyu Warahmatullaahi Wabarakaatuh, Assalaamu'alaina Wa'alaa 'Ibaadillaahish Shoolihiin. Asyhadu Allaa Ilaaha Illallaah, Waasyhadu Anna Muhammadan Rasuulullaah. Allahhumma Sholli 'Alaa Saidina Muhammad Wa 'Ala Aalihi Saidina Muhammad Kamaa Sholaita 'Ala Saidina Ibrahiim Wa 'Ala Aalihi Saidina Ibrahiim, Wa Baarik 'Ala Saidina Muhammad Wa 'Ala Aalihi Saidina Muhammad, Kamaa Baarakta 'Ala Saidina Ibrahiim Wa 'Ala Aalihi Saidina Ibrahiim, Fil Alamina Innaka Hamiidum Majiid”.

1. Salam

“Assalaamu”alaikum Wa Rohmatullahi Wa Barakatuh".

m. Tertib

\section{Metode Pembiasaan}

\section{Pengertian Metode Pembiasaaan}

Metode pembiasaan yaitu cara pembelajaran dengan memberikan stressing atau tekanan terhadap suatu pelajaran. ${ }^{4}$ Dengan memberikan waktu tertentu menghafal pelajaran dengan melakukan penekanan kepada anak didik atau siswa. Dengan pembiasaan secara terus menerus dalam jangka waktu yang terukur anak didik atau siswa terbukti dapat mengingat materi yang dihafalkan.

Menurut Pavlov ${ }^{5}$ otak manusia dapat dikondisikan terhadap situasi tertentu dengan rangsangan yang ditentukan. Artinya otak menerima rangsangan atau stimulus dalam waktu yang terus menerus maka akan mudah menerima masukan atau rangsangan. Dalam penelitiannya Pavlov menggunakan objek seekor anjing. Dia ingin mengetahui respon dari anjingnya terhadap rangsangan yang diberikan. Mula- mula ia membunyikan bel dan memberikan daging pada anjingnya, ketika melihat daging anjingnya mengeluarkan air liur. Hal ini ia lakukan secara terus menerus, sehingga ketika mendengar suara bel anjingnya akan mendekat dan mengeluarkan air

\footnotetext{
${ }^{4}$ Abu Ahmadi dan Drs., H., Munawar Sholeh, Psikologi Perkembangan, h. 118

${ }^{5}$ John W Santrock, Psikologi Pendidikan. Cetakan ke 2. Jakarta: Kencana 2008, h. 267.
}

178 | IQ (Ilmu Al-qur'an): Jurnal Pendidikan Islam | Volume 1 No.02 2018 
Peningkatan Kemampuan Hafalan Bacaan Sholat

Anak Usia 6 Tahun Melalui Metode Pembiasaan

liur, karena mengira akan diberi daging. Ternyata dengan pembiasan situasi ini ketika mendengar stimulus berupa bel, secara otomatis anjing merespon dengan mengeluarkan air liur. Teori dari Pavlov ini dapat dikembangkan untuk menghafal pelajaran, jika siswa atau anak didik sebagai objek diberikan rangsangan dengan kata -kata dari gurunya terhadap teks atau bacaan tertentu, dengan stimulus itu maka otak anak atau siswa akan terangsang. Jika hal ini dibiasakan terus menerus secara konsisten maka kemungkinan besar kemapuan hafalan anak akan meningkat.

Selanjutnya daya ingatan anak akan mencapai intensitas terbesar atau terbaik dan kuat saat usia anak $0-8$ tahun. Dalam usia tersebut daya tampung memori atau menghafal dapat masuk sebanyak-banyaknya. ${ }^{6}$

Oleh karena itu pembiasaan untuk menghafal tepat dilakukan pada masa atau periode ini. Menurut Al-Ghozali penanaman prinsip - prinsip Islam harus dimulai dengan hafalan, pemahaman, kemudian dianjutkan keyakinan dan pembenaran. ${ }^{7}$

Birkenfeld dan Al - Ghozali membagi emosi anak menjadi dua kategori yaitu, perasaan pada tingkat biologis (jasmaniah) dan perasaan pada tingkat jiwa (ruhaniyah). Diantara perasaan ruhaniyah adalah perasaan religious yaitu perasaan yang menyertai penghayatan keagamaan. Yang penting untuk dilakukan dalam mengembangkan perasaan ini adalah pembiasaan, motivasi, keteladanan, serta penciptaan situasi keagamaan. ${ }^{8}$ Bahwa dalam rangka menumbuhkembangkan kehidupan keagamaan anak yang meliputi upaya pembiasaan, teladan yang baik dan kasih sayang. Pembiasaan merupakan faktor yang sangat penting dalam menumbuhkan kehidupan keagamaan, karena anak belum mampu berpikir logis. ${ }^{9}$ Ide - ide keagamaan anak lebih banyak diterima berdasarkan otoritas orang tuanya. Oleh karena itu amatlah penting bagi orang tua dan juga guru madrasah sebagai Pembina pribadi bagi anak - anak untuk memberikan pembiasaan dan latihan sejak dini yang sesuai dengan ajaran agama. Ibnu Al-Jauzi mengatakan bahwa pembentukan yang utama adalah diwaktu kecil. Apabila seorang anak dibiarkan melakukan sesuatu yang kurang baik kemudian telah menjadi kebiasaannya maka akan sukarlah untuk meluruskannya.

\section{Langkah-Langkah Penerapan Metode Pembiasaan}

${ }^{6}$ Abu Ahmadi dan Drs., H., Munawar Sholeh, Psikologi Perkembangan, h. 94.

${ }^{7}$ Drs. H. A. Syaefudin, M Pd, 2005:153

${ }^{8}$ Abu Ahmadi dan Drs., H., Munawar Sholeh, Psikologi Perkembangan, h. 118.

${ }^{9}$ Djamiatul Islamiah. Jurnal Pendidikan Agama Bagi Anak antara Karakteristik dan Treatment. 2008, h. 12.

IQ (Ilmu Al-qur'an): Jurnal Pendidikan Islam | Volume 1 No.02 $2018 \mid 179$ 
Supaya pembiasaan itu dapat lekas tercapai dan baik hasilnya, sebaiknya melalui langkahlangkah sebagai berikut :

1. Mulailah pembiasaan itu sebelum terlambat, jadi sebelum anak itu mempunyai kebiasaan lain yang berlawanan dengan hal-hal yang akan dibiasakan.

2. Pembiasaan itu hendaklah terus menerus dijalankan secara teratur sehingga akhirnya menjadi suatu kebiasaan yang otomatis untuk itu dibutuhkan pengawasan.

3. Pendidikan hendaklah konsukuen, bersikap tegas dan tetap teguh terhadap pendiriannya yang telah diambilnya. Jangan member kesempatan kepada anak untuk melanggar pembiasaan yang telah ditetapkan.

4. Pembiasaan yang mula-mulanya mekanistis itu harus makin menjadi pembiasaan yang disertai kata hati anak itu sendiri. ${ }^{10}$

Menurut Syaiful Bahri Jamaroh metode pembiasaan ini disebut juga metode training yaitu suatu cara mengajar untuk menanamkan kebiasaankebiasaan tertentu. Juga sebagai sarana untuk memelihara kebiasaankebiasaan yang baik. Selain itu metode ini dapat digunakan untuk memperoleh suatu ketangkasan, ketepatan, kesempatan dan keterampilan. ${ }^{11}$

Metode drill menurut Zakiah Daradjat penggunaan istilah "latihan" sering disamakan artinya dengan istilah "ulangan". Padahal maksudnya berbeda. Latihan bermaksud agar pengetahuan dan kecakapan tertentu dapat menjadi milik anak didik dan dikuasai sepenuhnya sedangkan ulangan hanyalah untuk sekedar mengukur sejauh mana dia telah menyerap pengajaran tersebut. ${ }^{12}$.( Zakiah Daradjat,1995:302 )

Pengajaran yang diberikan melalui metode drill atau pembiasaan dengan baik selalu akan menghasilkan hal-hal sebagai berikut :

a. Anak didik itu akan dapat mempergunakan daya pikirannya yang makin lama akan bertambah baik, karena dengan pengajaran yang baik maka anak didik akan menjadi lebih teratur dan lebih teliti dalam mendorong daya ingatnya. Ini berarti daya pikir bertambah.

\footnotetext{
${ }^{10}$ Ngalim Purwanto, Ilmu Pendidikan Teoritis dan Praktis. Bandung : Remaja Karya. 1995, h. 178.

${ }^{11}$ Syaiful Bahri Djamarah, Psikologi Belajar. Jakarta : Rineka Cipta. 2008, h. 242

12 Darajat, Zakiah, Pendidikan Islam dalam Keluarga dan Sekolah, (Jakarta: CV Ruhama, 1995) dalam skripsi Parsaulian, Sari Domu, Studi Perkembangan Kemampuan Menghapal Surat Al-Fatihah Anak Usia 5 Tahun Di Kampung Teleng Padang Sidempuan,2007.
} 
Peningkatan Kemampuan Hafalan Bacaan Sholat

Anak Usia 6 Tahun Melalui Metode Pembiasaan

b. Pengetahuan anak didik bertambah dalam berbagai segi, dan anak didik tersebut akan memperoleh pemahaman yang lebih baik dan mendalam. Guru berkewajiban menyelidiki sejauh mana kemajuaan yang telah dicapai oleh anak didik dalam proses belajar mengajar.

Dalam menerapkan metode drill atau pembiasaan ini harus diperhatikan pula antara lain :

1. harus diusahakan latihan tersebut jangan sampai membosankan anak didik, karena waktu yang digunakan cukup singkat.

2. Latihan betul-betul diatur sedemikian rupa sehingga latihan itu menarik perhatian anak didik dalam hal ini guru harus menumbuhkan motif untuk belajar.

3. Agar anak didik tidak ragu maka anak didik lebih dahulu diberikan pengertian dasar tentang materi yang akan diberikan. Melihat hal-hal tersebut di atas maka guru pada saat memberikan latihan haruslah siap lebih dahulu, tidak secara spontanitas saja memberi latihan sehingga waktu mengadakan evaluasi terhadap hasil latihan segera guru dapat melihat segi-segi kemajuan anak didik diantara daya tanggap, keterampilan dan ketepatan berpikir dari tiap-tiap anak didik diberi tugas latihan. Sebagai suatu metode yang diakui banyak mempunyai kelebihan juga tidak dapat disangkal bahwa metode drill atau pembiasaan mempunyai beberapa kelemahan. Maka dari itu, guru yang ingin mempergunakan metode ini kiranya memahami karakteristik metode ini.

\section{a. Kelebihan Metode Pembiasaan}

1. Untuk memperoleh kecakapan motorik, seperti menulis, melafalkan huruf, kata-kata atau kalimat, membuat alat-alat dan keterampilan menggunakaan peralatan olah raga.

2. Untuk memperoleh kecakapan mental seperti dalam perkalian, penjumahan, pengurangan, pembagian, tanda-tanda (simbol) dan sebagainya.

3. Untuk memperoleh kecakapan dalam bentuk asosiasi yang dibuat.

4. Pembentukan kebiasaan yang dilakukan dan menambah ketepatan serta kecepatan pelaksanaan.

5. Pemanfaatan kebiasaan-kebiasaan yang tidak memerlukan konsentrasi dalam pelaksanaannya.

6. pembentukan kebiasaan-kebiasaan membuat gerakan-garakan yang kompleks, rumit menjadi lebih otomatis.

\section{b. Kelemahan Metode Pembiasaan (latihan )}

IQ (Ilmu Al-qur'an): Jurnal Pendidikan Islam | Volume 1 No.02 2018 | 181 
1. Menghambat bakat dan inisiatif siswa, karena siswa lebih banyak dibawa kepada penyesuaian dan diarahkan jauh dari pengetian.

2. Menimbulkan penyesuaian secara statis kepada lingkungan.

3. Kadang-kadang latihan yang dilaksanakan secara berulangulang merupakan hal monoton, mudah membosankan.

4. Membentuk kebiasaan yang kaku, karena bersifat otomatis.

5. Dapat menimbulkan verbalisme.

\section{Kesulitan Anak Menghafal Bacaan Sholat}

Menurut Putra dan Issetyadi (dalam Saptadi, 2012) kualitas menghafal bacaan al-quran dikarenakan dua faktor, yaitu faktor internal dan eksternal. Faktor internal yaitu: kondisi emosi, keyakinan, kebiasaan dan cara memperoleh stimulus. Faktor eksternal yaitu: lingkungan belajar dan nutrisi tubuh.

Berdasarkan kajian diatas jika anak dikarenakan tidak mempunyai salah satunya sifat sabar (emosi) maka anak akan sulit menghafal bacaan al-quran karena anak tidak fokus ingin lekas selesai. Lingkungan keluarga, orangtua tidak membiasakan anak tersebut untuk belajar bacaan sholat. Ketika waktu sholat, orangtua membimbing anak untuk beribadah secara benar ketika anak tidak lancar orangtua mengoreksi lalu membenarkan bacaan sholat tersebut. Gizi juga sangat diperlukan dalam menghafal karena anak juga membutuhkan energi. Jika semua hal itu tidak bisa dipenuhi anak, anak akan sulit umtuk menghafal bacaan sholat dan hafalannya pun tidak berkualitas.

\section{Metode Penelitian}

Metode penelitian yang digunakan adalah penelitian tindakan yang bersifat partisipatif dan kolaboratif. Perencanaan penelitian ini menggunakan metode penelitian tindakan model Kemmis dan Taggart dengan tiga siklus, dimana setiap siklus mempunyai langkah-langkah seperti: (1) perencanaan, (2) tindakan/ acting, (3) pengamatan/ observing, (4) Refleksi atau hasil observasi. Berdasarkan refleksi ini pula suatu perbaikan tindakan (replanning) selanjutnya ditentukan (Kusumah dan Dwitagama, 2009: 40).

\section{Hasil Dan Pembahasan}

182 | IQ (Ilmu Al-qur'an): Jurnal Pendidikan Islam | Volume 1 No.02 2018 
Peningkatan Kemampuan Hafalan Bacaan Sholat

Anak Usia 6 Tahun Melalui Metode Pembiasaan

\section{Siklus I}

\section{Minggu pertama}

Kondisi awal ketuntasan hafalan bacaan sholat S adalah 36\%, yaitu dari 11 hafalan bacaan doa sholat yaitu takbirotul ihrom, iftitah, surat al fatihah, surat pendek, ruku', I'tidal, sujud, duduk diantara dua sujud, tasyahud awal, tasyahud akhir dan salam, baru 4 bacaan doa yang sudah hafal yaitu takbirotul ihrom, surat alfatihah, surat pendek dan salam. Setiap hari S dilatih untuk praktek sholat, subjek melakukan praktek sholat dengan diajarkan bacaan sholat sesuai gerakan sholat. Saat subjek sedang tidak mau melakukan praktek maka peneliti membacakan bacaanbacaan sholat dan $\mathrm{S}$ hanya mendengarkan, metode lain yang peneliti lakukan adalah bersamasama mengajaknya sholat namun suara peneliti sedikit berbisik sampai $\mathrm{S}$ mendengar dan mampu mengikuti bacaan sholat selama sholat. Jadwal pembiasaan pada sesi ini adalah saat sholat zuhur dan magrib.

\section{Minggu kedua}

Di minggu ini S mengalami kemajuan ketuntasan hafalan mencapai 54\%, dari 11 hafalan doa sholat, S mampu menambah dua bacaan sholat menjadi enam bacaan doa sholat. Dua doa yang dihafal S pada minggu ini adalah doa ruku' dan sujud. Jadwal pembiasaan pada sesi ini adalah saat sholat zuhur dan magrib

\section{Siklus II}

\section{Minggu Ketiga}

Di sesi ini jadwal pembiasaan ditambah yaitu saat isya, jadi ada tiga waktu sholat yaitu dzuhur, magrib dan isya. Di minggu ini $\mathrm{S}$ mengalami kemajuan ketuntasan hafalan mencapai $72 \%, \mathrm{~S}$ mampu menambah dua bacaan sholat yaitu I'tidal dan duduk diantara dua sujud.sehingga total ketuntasan $\mathrm{S}$ dalam menghafal adalah 8 dari 11 bacaan sholat.

\section{Minggu Keempat}

Kondisi ketuntasan $\mathrm{S}$ di minggu keempat ini mengalami kemajuan menjadi $81 \%$. $\mathrm{S}$ mampu menambah satu bacaan sholat yaitu doa iftitah. S sudah mampu menghafalnya dengan lancar. Total ketuntasan yang S capai adalah 9 dari 11 bacaan sholat.

\section{Sesi III}

\section{Minggu Kelima}

Pada sesi ini jadwal pembiasaan ditambah menjadi 5 waktu sholat. Namun di minggu ini yang paling berat $\mathrm{S}$ lakukan adalah sholat subuh sehingga hanya 3 hari dilakukan. Di minggu ini total IQ (Ilmu Al-qur'an): Jurnal Pendidikan Islam | Volume 1 No.02 2018 | 183 
ketuntasan yang S capai adalah 10 dari 11 bacaan sholat, atau $90 \%$ S sudah bisa bacaan tasyahud awal meskipun tidak terlalu lancar dan masih dibimbing.

\section{Minggu Keenam}

Sesi ini adalah sesi terakhir di penelitian ini, minggu ini S mengerjakan sholat lima waktu, dengan diberikan reward jika berhasil sholat 5 waktu dengan bacaan yang benar saat weekend akan diajak berenang. Waktu untuk melakukan review bacaan sholat adalah saat sholat magrib atau isya. Jadi selama 6 minggu ini setiap waktu magrib atau isya, S membaca doa sholat dengan suara keras. Di minggu ini seluruh doa sholat sudah dihafal namun masih ada kekurangan pada tasyahud akhir, S masih suka lupa saat awal "wa barik 'alaa sayyidina muhammad" dengan "kama baarokta 'ala sayyidina ibroohim" namun untuk kalimat "wa 'ala ali sayyidina Muhammad dan wa 'ala ali sayyidina ibrohim" bisa ia lanjutkan sendiri. Dan selanjutnya sampai akhir tasyahud dapat ia hafal.

Berikut ini grafik keberhasilan capaian hafalan bacaan sholat $\mathrm{S}$

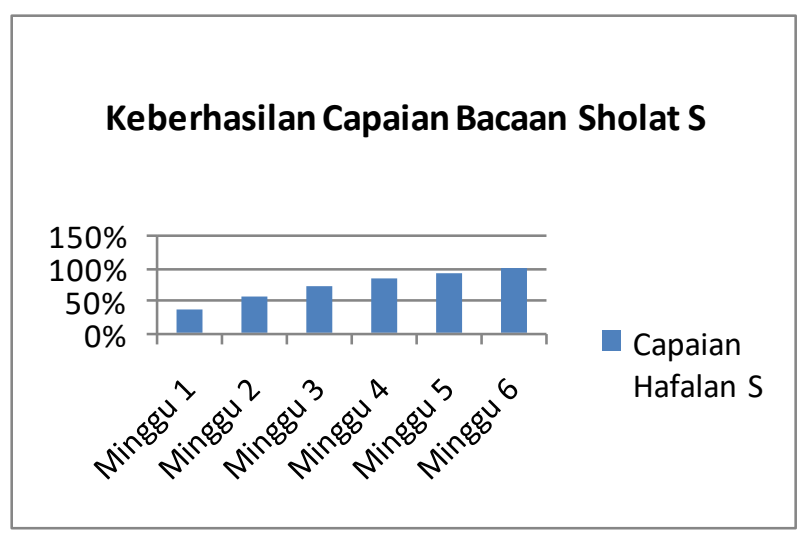

Dengan metode pembiasaan dapat dilihat kemajuan hafalan doa sholat $\mathrm{S}$ cukup baik. Menurut Djamarah, metode pembiasaan adalah suatu cara mengajar untuk menanamkan kebiasaan-kebiasaan tertentu. Juga sebagai sarana untuk memelihara kebiasaan-kebiasaan yang baik.

Didukung dengan teori Pavlov bahwa otak manusia dapat dikondisikan terhadap situasi tertentu dengan rangsangan yang ditentukan. Artinya otak menerima rangsangan atau stimulus dalam waktu yang terus menerus maka akan mudah menerima masukan atau rangsangan. 


\section{Simpulan}

Penggunaan metode pembiasaan untuk hafalan bacaan sholat pada $S$ terbukti dapat meningkatkan kemampuan menghafal, dengan bukti peningkatan kemampuan hafalan dalam prosentase ketuntasan

belajar pada setiap siklus.

2. Dengan menggunakan metode pembiasaan yang disertai reward terbukti dapat meningkatkan motivasi dan semangat menghafal serta sholat lima waktu pada S. Hal ini tampak dengan tidak malasnya untuk bangun pagi dan melakukan sholat dengan perasaan senang.

3. Ketuntasan hafalan bacaan sholat dapat ditingkatkan melalui model pembelajaran pembiasaan, yaitu dari 36\% \% atau 4 hafalan bacaan sholat menjadi $90 \%$ atau 10 hafalan bacaan sholat.

\section{Saran}

Berdasarkan kesimpulan yang telah dikemukakan diatas, maka dapat disampaikan beberapa saran sebagai rekomendasi hasil penelitian sebagai berikut:

Pertama, Orangtua hendaknya membiasakan hafalan bacaan sholat sejak dini, sehingga lebih mudah mengajarkan dan anak lebih cepat hafal, dengan memberi waktu 10 - 15 menit pada setiap sesi atau bisa dilakukan saat praktik sholat sesuai waktu sholat. Kedua, metode pembiasaan dapat diterapkan untuk meningkatkan hafalan bacaan sholat. Dan ketiga, untuk lebih mudah mengajak anak sholat,bisa disertakan cerita-cerita islam seperti tentang sholat dan rukun islam. 
Desy Ayuningrum

\section{Daftar Pustaka}

Ahmadi, Abu., Drs., H., Munawar Sholeh, Psikologi Perkembangan. Cetakan I. Jakarta : Rineka Cipta. 2005

Clark, , Eve V, Old and New Words Forms for New Meaning dalam Men dan Ratna, coining new words: 2000.

Darajat, Zakiah, Pendidikan Islam dalam Keluarga dan Sekolah, (Jakarta: CV Ruhama, 1995) dalam skripsi Parsaulian, Sari Domu, Studi Perkembangan Kemampuan Menghapal Surat Al-Fatihah Anak Usia 5 Tahun Di Kampung Teleng Padang Sidempuan,2007.

Djamarah, Syaiful Bahri. Psikologi Belajar. Jakarta : Rineka Cipta. 2008

Djamiatul Islamiah. Jurnal Pendidikan Agama Bagi Anak antara Karakteristik dan Treatment. 2008

Kusumah, Wijaya dan Dedi Dwitagama. Mengenal Penelitian Tindakan Kelas. Jakarta : PT Indeks. 2009

Purwanto, Ngalim. Ilmu Pendidikan Teoritis dan Praktis. Bandung : Remaja Karya. 1995

Santrock, John W., Psikologi Pendidikan. Cetakan ke 2. Jakarta : Kencana. 2008 